\title{
Estimate of intense rainfall equation parameters for rainfall stations of the Paraíba State, Brazil ${ }^{1}$
}

\author{
Alcinei Ribeiro Campos², João Batista Lopes da Silva ${ }^{3}$, \\ Glenio Guimarães Santos ${ }^{4}$, Rafael Felippe Ratke ${ }^{5}$, Itauane Oliveira de Aquino ${ }^{2}$
}

\section{ABSTRACT}

Rainfall is the primary water source for hydrographic basins. Hence, the quantification and knowledge of its temporal and spatial distribution are indispensable in dimensioning hydraulic projects. This study aimed at assessing the fit of a series of rainfall data to different probability models, as well as estimating parameters of the intensity-duration-frequency (IDF) equation for rain stations of the Paraíba State, Brazil. The rainfall data of each station were obtained from the Brazilian Water Agency databanks. To estimate the maximum daily rainfall of each station and return period $(5,10,15,25$, 50 and 100 years), the following probability distributions were used: Gumbel, Log-Normal II, Log-Normal III, Pearson III and Log-Pearson III. The estimation of rainfall in durations of 5-1,440 min was carried out by daily rainfall disaggregation. The adjustment of the IDF equation was performed via nonlinear multiple regression, using the nonlinear generalized reduced gradient interaction method. When compared to the data observed, the intense rainfall equations for most stations showed goodness of fit with coefficients of determination above 0.99 , which supports the methodology applied in this study.

KEYWORDS: Hydrology; intensity-duration-frequency equation; rainfall.

\section{INTRODUCTION}

Water is a natural resource with a wide range of uses and is vital to the human development. Maintaining this finite resource at adequate standards of quality and quantity for its multiple uses is a challenge to society. Rainfall is the primary source of water for hydrographic basins. As such, its quantification and the knowledge of how it is temporally and spatially

\section{RESUMO}

Estimativa de parâmetros das equações de chuvas intensas para estações pluviométricas do Estado da Paraíba, Brasil

As chuvas constituem-se na principal fonte de água para bacias hidrográficas. Por isso, a quantificação e o conhecimento de sua distribuição temporal e espacial são indispensáveis para o dimensionamento de projetos hidráulicos. Objetivou-se avaliar a aderência de séries de dados pluviométricos a diferentes modelos probabilísticos e estimar parâmetros da equação de intensidadeduração-frequência (IDF) para estações pluviométricas do Estado da Paraíba. Os dados pluviométricos de cada estação foram obtidos a partir do banco de dados da Agência Nacional de Águas. Para estimar as precipitações máximas diárias de cada estação e o período de retorno (5, $10,15,25,50$ e 100 anos), foram utilizadas as seguintes distribuições de probabilidade: Gumbel, Log-Normal II, Log-Normal III, Pearson III e Log-Pearson III. A estimativa das chuvas nas durações de 5-1.440 min foi realizada pela desagregação das precipitações pluviométricas diárias. O ajuste da equação IDF foi realizado por meio de regressão múltipla não linear, com uso do método de interação de gradação reduzida generalizada não linear. As equações de chuvas intensas para a maioria das estações, quando comparadas aos dados observados, apresentaram ajustes com coeficientes de determinação acima de 0,99 , o que referenda a metodologia empregada neste trabalho.

PALAVRAS-CHAVE: Hidrologia; equação intensidade-duraçãofrequência; pluviosidade.

distributed are essential in studies related to irrigation needs, water availability for domestic and industrial uses, soil erosion, flood control and water projects, among others (Oliveira et al. 2005, Araújo et al. 2008, Santos et al. 2010, Castro et al. 2011).

According to Mello et al. (2008), the 21st century should experience a great frequency of extreme temperature and rainfall events. These maximum rainfalls, also denominated intense rainfalls

1. Manuscript received in Oct./2016 and accepted for publication in Feb./2017 (http://dx.doi.org/10.1590/1983-40632016v4743821). 2. Universidade Federal do Rio Grande do Sul, Faculdade de Agronomia, Porto Alegre, RS, Brazil.

E-mails: alcineicampos@gmail.com, itauane2010@gmail.com.

3. Universidade Federal do Sul da Bahia, Campus Paulo Freire, Teixeira de Freitas, BA, Brazil. E-mail: silvabl@yahoo.com.br. 4. Universidade Federal de Goiás, Escola de Agronomia, Goiânia, GO, Brazil.E-mail: gleniogm@gmail.com.

5. Universidade Federal do Piauí, Bom Jesus, PI, Brazil.E-mail: rfratke@gmail.com. 
(Silva et al. 2012, Souza et al. 2012, Aragão et al. 2013), produce a large volume of water in a short period of time. As such, they are apt to cause large surface flows and considerable damage in both urban and agricultural areas in the form of floods, dam ruptures, inundation of cultivated land, soil erosion, silting and contamination of water bodies (Cecílio et al. 2009, Santos et al. 2009). The knowledge of rainfall volume at a specific time and space is important for planning soil and water conservation practices and hydrographic basin management, in order to establish the flow used in different types of hydraulic projects (Back 2009, Cecílio et al. 2009, Santos et al. 2009).

To characterize rainfall, it is necessary to know its duration, intensity and frequency of occurrence. These relationships are commonly denominated intensity-duration-frequency (IDF) curves, one of the most widely used methodologies in rainfall-flow transformation processes (Damé et al. 2008). Intense rainfall is determined by empirical adjustments of IDF equation parameters, derived from rainfall data for each of the stations (Santos et al. 2009, Back et al. 2012). The parameters of the intense rainfall equation can be obtained via nonlinear multiple regression, based on information extracted from the series of rainfall data (Campos et al. 2014), which do not always contain duration, but are composed of daily records. However, it is necessary to know which rainfalls lasted less than $24 \mathrm{~h}$, in order to adjust IDF equations (Aragão et al. 2013). One alternative is disaggregation based on proportionality factors, which makes possible to obtain rainfall duration in minutes (Cetesb 1986, Garcia et al. 2011, Aragão et al. 2013).

In the Brazilian Paraíba State, pioneering studies on intense rainfall were conducted by
Pfafstetter (1957), who used rainfall records from stations located in the cities of João Pessoa and São Gonçalo. For these areas, Pfafstetter (1957) adjusted the parameters of the relationship between rainfall and return period for different durations. In other study, Souza (1972) used data from João Pessoa to develop the IDF equation for this station. Since these outdated reports were the only ones available for Paraíba, a State that depends greatly on the efficient use of water for its cropping activities, it is required to update and estimate them for other locations in this region.

Due to the significant lack of information about rainfall intensity-duration-frequency (IDF) for most locations in Paraíba, and given the importance of knowing such information for the design of irrigation projects, this study aimed at estimating the parameters of the IDF equation for rainfall stations in this State.

\section{MATERIAL AND METHODS}

The study was carried out in 2014, at the Universidade Federal do Piauí, in Bom Jesus, Piauí State, Brazil. Daily rainfall data were collected from 132 stations in the Paraíba State, obtained from the Brazilian Water Agency databank (Brasil 2012).

First, the consistency of the data series of each station was analyzed, and those with less than 16 years of observation were excluded, leaving only one per municipality, and a total of ninety stations (Figure 1).

A series of mean maximum 1-day rainfalls was obtained for the following return periods: $5,10,15$, 25, 50 and 100 years. The probability distributions

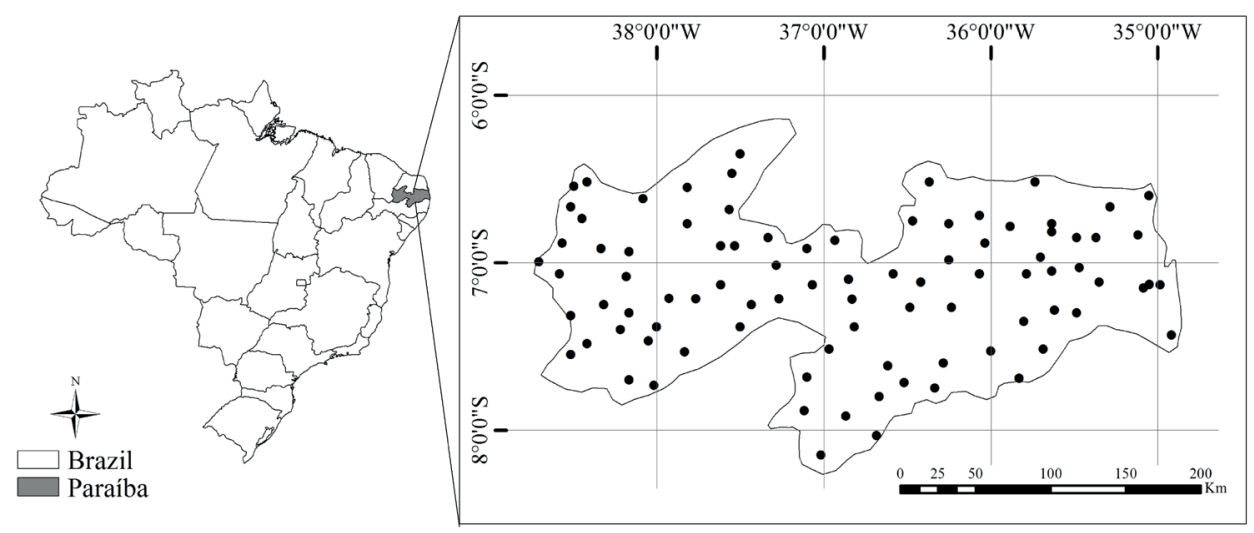

Figure 1. Location of ninety rainfall stations used to estimate the intensity-duration-frequency (IDF) equations for the Paraíba State. Source: Brasil (2012). 
used were: Gumbel, Log-Normal II, Log-Normal III, Pearson III and Log-Pearson III (Santos 2010). For each station, the maximum rainfall in which the data series showed the best fit to the probability model was selected, i.e., the distribution model with the lowest standard error. All these stages were conducted using the SisCAH software (Sousa et al. 2009). Afterwards, the probability model that best fitted the data series was determined to estimate the maximum daily rainfall, and the number of occurrences of each model was counted.

Once the maximum daily rainfalls had been established, 1-day rainfall disaggregation was performed at 5, 10, 15, 20, 25, 30, 60, 360, 480, 600, 720 and $1440 \mathrm{~min}$, using the coefficients from the rainfall disaggregation method proposed by Cetesb (1979) (Table 1).

Once the fit of distribution data to the probability model had been assessed and disaggregation was achieved at shorter times, the parameters $\mathrm{K}, \mathrm{a}, \mathrm{b}$ and $\mathrm{c}$ of the intensity-duration-frequency equation were established (Equation 1), according to Pfafstetter (1982):

$$
\mathrm{Mi}=\frac{\mathrm{K} \cdot \mathrm{RP}}{(\mathrm{t}+\mathrm{b})^{\mathrm{c}}}
$$

where $\mathrm{Mi}$ is the mean maximum rainfall, in $\mathrm{mm} \mathrm{h}^{-1}$; $\mathrm{RP}$ the return period, in years; $t$ the rainfall duration, in min; and $\mathrm{K}, \mathrm{a}, \mathrm{b}$, and $\mathrm{c}$ the parameters adjusted based on the rainfall data for the location.

The IDF equation parameters were adjusted via nonlinear multiple regression, using the generalized reduced gradient interaction method, and goodness of fit was assessed based on the coefficient of determination $\left(r^{2}\right)$ estimated by the Equation 2:

Table 1. Coefficients used for daily rainfall disaggregation in shorter time intervals.

\begin{tabular}{cc}
\hline Rainfall-flow transformation interval & Coefficient \\
\hline 1 day to $24 \mathrm{~h}$ & 1.14 \\
1 day to $12 \mathrm{~h}$ & 0.85 \\
$24 \mathrm{~h}$ to $10 \mathrm{~h}$ & 0.82 \\
$24 \mathrm{~h}$ to $8 \mathrm{~h}$ & 0.78 \\
$24 \mathrm{~h}$ to $6 \mathrm{~h}$ & 0.72 \\
$24 \mathrm{~h}$ to $1 \mathrm{~h}$ & 0.42 \\
$1 \mathrm{~h}$ to $30 \mathrm{~min}$ & 0.74 \\
$1 \mathrm{~h}$ to $25 \mathrm{~min}$ & 0.91 \\
$1 \mathrm{~h}$ to $20 \mathrm{~min}$ & 0.81 \\
$1 \mathrm{~h}$ to $15 \mathrm{~min}$ & 0.70 \\
$1 \mathrm{~h}$ to $10 \mathrm{~min}$ & 0.54 \\
$1 \mathrm{~h}$ to $5 \mathrm{~min}$ & 0.34 \\
\hline Source: Cetesb (1979).
\end{tabular}

$$
\mathrm{r}^{2}=\left(\frac{\sum(\mathrm{x}-\overline{\mathrm{x}}) \cdot(\mathrm{y}-\overline{\mathrm{y}})}{\sqrt{\sum(\mathrm{x}-\overline{\mathrm{x}}) \cdot(\mathrm{y}-\overline{\mathrm{y}})}}\right)^{2}
$$

where $\mathrm{x}$ is the observed values; $\overline{\mathrm{x}}$ the observed mean values; $y$ the estimated values; and $\bar{y}$ the estimated mean values.

Goodness of fit was also evaluated using the regression equation of data observed in relation to the estimated data, considering, in this case, the angular coefficient of the straight line.

After the parameters $(K, a, b$ and $c)$ were adjusted, they were used to estimate the maximum rainfall intensity for the return period of 25 years, as well as duration of 5, 30, 60, 360, 720 and 1,440 min. Next, these data were regionalized for all the Paraíba State, using the kriging method and ArcGis 10 software.

\section{RESULTS AND DISCUSSION}

From the probability models that exhibited the best fit for the series of rainfall data, the highest standard error observed was 41.83. Considering the standard error values obtained, more than one of the probability models provided a good fit to a same data series, according to the return period. This indicates that the model that best fits each return period should be used to estimate the maximum rainfall in different return periods. Lyra et al. (2006) observed the goodness of fit of different probability models to estimate rains at different periods of the year, indicating that fitting models is directly linked to the temporal distribution of rainfall. This confirms the need to apply more than one probability model to analyses covering different times, providing a greater security to projects dimensioned according to these estimated rainfall values.

Of the ninety stations studied, the Log-Normal III model showed the best fit to the data series ( $49.3 \%$ of the stations), followed by the Gumbel model, with $16.1 \%$ of the stations. The models with the poorest fit were Pearson III, Log-Pearson III and Log-Normal II, with $14.1 \%, 12.8 \%$ and $7.8 \%$ of the stations, respectively (Figure 2). Martins et al. (2011) estimated the maximum flow and rainfall using probability models, also obtaining a better fit with the Log-Normal III distribution model. These findings are similar to those reported by Silva et al. (2003a), in determining the parameters of IDF equations for the Tocantins State, Brazil. These results confirm that, in addition to the Gumbel model (Santos et al. 2009), widely recommended in literature, the Log-Normal III may also be useful to estimate rainfall 


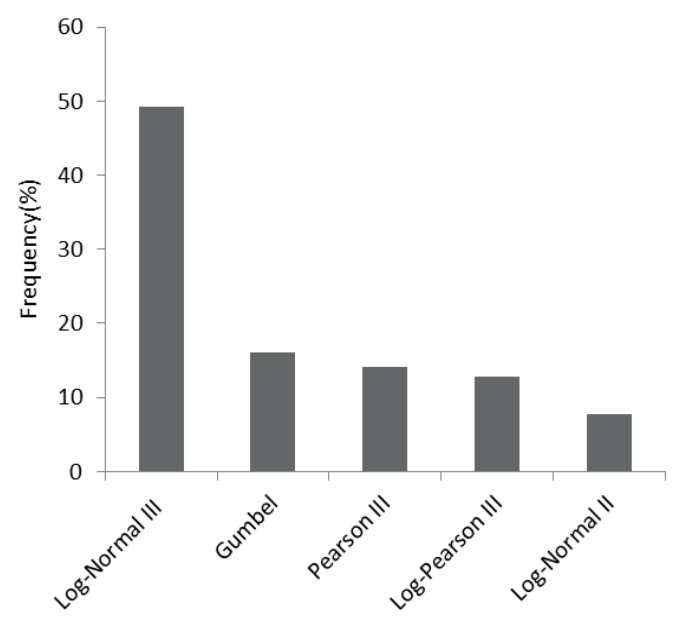

Figure 2. Frequency of the best fits to the respective probability distribution models. in different return periods, having the lowest standard error of the estimates as a fit criterion.

The values of the fitting IDF parameters varied significantly from one station to another. The $\mathrm{K}$ parameter estimates ranged between 473.139 and 2095.776, respectively for the Remígio and Santa Rita stations. Moruzzi \& Oliveira (2009), Souza et al. (2012) and Silva et al. (2012) also reported a similar variation for this parameter, attributing that to the interaction between $\mathrm{K}$ and the other IDF parameters. The estimates of the parameter "a" ranged between 0.025 and 0.386 , respectively for the Sousa and Santa Rita stations; parameter "b" between 9.836 and 30.214, respectively for the Remígio and Santa Rita stations; and parameter "c" between 0.745 and 0.915 , respectively for the Remígio and Santa Rita stations (Table 2). Similar

Table 2. Adjusted values for parameters of the intensity-duration-frequency (IDF) equation ${ }^{1}$ and respective determination coefficient $\left(\mathrm{r}^{2}\right)$ for each studied rainfall station in the Paraíba State, Brazil.

\begin{tabular}{|c|c|c|c|c|c|c|c|c|c|c|c|c|c|}
\hline City & Code & $\mathrm{K}$ & $\mathrm{a}$ & $\mathrm{b}$ & $\mathrm{c}$ & $\mathrm{r}^{2}$ & City & Code & $\mathrm{K}$ & $\mathrm{a}$ & $\mathrm{b}$ & $\mathrm{c}$ & $\mathrm{r}^{2}$ \\
\hline Água Branca & 737022 & $1,070.08$ & 0.110 & 13.110 & 0.780 & 0.999 & Mogeiro & 735010 & 807.748 & 0.199 & 13.511 & 0.783 & 0.998 \\
\hline Aguiar & 738025 & 981.794 & 0.186 & 12.030 & 0.768 & 0.999 & Monteiro & 737014 & 623.267 & 0.258 & 11.114 & 0.759 & 0.998 \\
\hline Alagoa Grande & 735033 & $1,141.473$ & 0.187 & 18.694 & 0.829 & 0.992 & Mulungu & 735009 & 827.096 & 0.224 & 16.065 & 0.806 & 0.994 \\
\hline Alhandra & 734008 & 973.248 & 0.207 & 10.327 & 0.751 & 0.998 & Nova Olinda & 738014 & $1,240.531$ & 0.178 & 13.314 & 0.781 & 0.998 \\
\hline Aracagi & 635027 & 891.732 & 0.202 & 13.420 & 0.782 & 0.998 & Olho D’água & 737011 & $1,166.909$ & 0.112 & 13.216 & 0.780 & 0.998 \\
\hline Araruna & 635028 & 978.242 & 0.228 & 14.452 & 0.792 & 0.996 & Olivedos & 636036 & $1,170.203$ & 0.289 & 18.511 & 0.828 & 0.987 \\
\hline Areia & 635030 & 982.504 & 0.214 & 15.391 & 0.800 & 0.996 & Passagem & 737010 & $1,087.539$ & 0.136 & 13.373 & 0.782 & 0.998 \\
\hline Bananeiras & 635033 & 912.592 & 0.169 & 13.581 & 0.783 & 0.998 & Pedra Lavrada & 636037 & $1,049.774$ & 0.167 & 17.593 & 0.820 & 0.995 \\
\hline Barra de Santa Rosa & 636032 & 483.566 & 0.256 & 10.806 & 0.756 & 0.999 & Piancó & 737006 & $1,053.249$ & 0.164 & 13.421 & 0.782 & 0.998 \\
\hline Barra de São Miguel & 736025 & $1,111.353$ & 0.266 & 17.977 & 0.823 & 0.992 & Picuí & 636038 & $1,010.135$ & 0.311 & 21.656 & 0.853 & 0.982 \\
\hline Boa Ventura & 738012 & $1,172.065$ & 0.083 & 12.633 & 0.774 & 0.999 & Pilar & 735035 & 756.675 & 0.245 & 10.795 & 0.756 & 0.999 \\
\hline Bonito de Santa Fé & 738022 & 1.129 .402 & 0.114 & 12.985 & 0.778 & 0.999 & Pilões & 638046 & 915.392 & 0.149 & 11.097 & 0.759 & 0.999 \\
\hline Boqueirão & 735124 & 612.044 & 0.246 & 11.226 & 0.760 & 0.999 & Pocinhos & 736014 & 732.276 & 0.241 & 15.806 & 0.804 & 0.996 \\
\hline Brejo do Cruz & 637023 & $1,143.916$ & 0.265 & 18.479 & 0.827 & 0.989 & Pombal & 637032 & 896.259 & 0.138 & 12.121 & 0.769 & 0.999 \\
\hline Cabaceiras & 736022 & 596.260 & 0.259 & 11.816 & 0.766 & 0.999 & Prata & 737004 & $1,144.219$ & 0.132 & 13.172 & 0.780 & 0.998 \\
\hline Cajazeiras & 638028 & 981.336 & 0.134 & 11.635 & 0.764 & 0.999 & Remígio & 636031 & 473.139 & 0.272 & 9.836 & 0.745 & 0.998 \\
\hline Camalau & 736021 & $1,274.816$ & 0.150 & 12.913 & 0.777 & 0.998 & Salgadinho & 736010 & 713.824 & 0.234 & 11.402 & 0.762 & 0.999 \\
\hline Campina Grande & 736024 & 801.209 & 0.253 & 15.254 & 0.799 & 0.995 & Santa Luzia & 636042 & 929.464 & 0.113 & 13.712 & 0.785 & 0.998 \\
\hline Catolé do Rocha & 637030 & $1,003.170$ & 0.125 & 12.540 & 0.773 & 0.995 & Santa Rita & 734001 & $2,095.776$ & 0.386 & 30.214 & 0.915 & 0.957 \\
\hline Conceição & 738020 & $1,147.336$ & 0.227 & 16.158 & 0.807 & 0.994 & Santa Teresinha & 735036 & 992.153 & 0.179 & 11.849 & 0.767 & 0.999 \\
\hline Condado & 637028 & $1,034.455$ & 0.085 & 12.742 & 0.775 & 0.999 & Santana dos Garrotes & 738019 & 832.018 & 0.170 & 13.502 & 0.783 & 0.998 \\
\hline Congo & 736018 & $1,139.564$ & 0.185 & 16.556 & 0.811 & 0.995 & São João do Cariri & 736020 & 666.983 & 0.231 & 11.275 & 0.761 & 0.999 \\
\hline Coremas & 737021 & $1,274.682$ & 0.091 & 12.725 & 0.775 & 0.999 & São João do Rio do Peixe & 638032 & 937.692 & 0.135 & 11.175 & 0.760 & 0.999 \\
\hline Cruz do Espírito Santo & 735019 & 995.833 & 0.140 & 12.676 & 0.775 & 0.998 & São João do Tigre & 836001 & 968.835 & 0.241 & 16.313 & 0.809 & 0.995 \\
\hline Cuité & 636040 & 901.149 & 0.136 & 13.724 & 0.785 & 0.998 & São João da Lagoa Tapada & 638049 & $1,272.876$ & 0.120 & 13.239 & 0.780 & 0.998 \\
\hline Desterro & 637029 & $1,200.708$ & 0.336 & 23.953 & 0.871 & 0.977 & São João de Espinharas & 637034 & $1,064.522$ & 0.130 & 11.857 & 0.767 & 0.999 \\
\hline Fagundes & 735018 & 942.259 & 0.134 & 13.327 & 0.781 & 0.998 & São José de Piranhas & 738024 & 972.242 & 0.140 & 11.514 & 0.763 & 1.000 \\
\hline Guarabira & 635040 & $1,142.183$ & 0.223 & 15.405 & 0.800 & 0.996 & São José dos Cordeiros & 736011 & 1.063 .892 & 0.097 & 13.283 & 0.781 & 0.998 \\
\hline Gurjão & 736016 & $1,296.963$ & 0.160 & 14.184 & 0.789 & 0.997 & São Mamede & 637037 & $1,222.403$ & 0.097 & 13.224 & 0.780 & 0.998 \\
\hline Ibiara & 738018 & $1,267.511$ & 0.147 & 13.472 & 0.782 & 0.998 & São Sebastião do Umbuzeiro & 837000 & $1,005.777$ & 0.111 & 14.074 & 0.788 & 0.998 \\
\hline Imaculada & 737017 & 824.171 & 0.172 & 11.411 & 0.762 & 0.999 & Serra Branca & 736017 & $1,132.579$ & 0.147 & 14.479 & 0.792 & 0.997 \\
\hline Ingá & 735017 & 649.214 & 0.213 & 12.741 & 0.775 & 0.999 & Serra Grande & 738010 & $1,033.868$ & 0.167 & 12.047 & 0.768 & 0.999 \\
\hline Juazeirinho & 736015 & $1,020.790$ & 0.086 & 13.140 & 0.779 & 0.998 & Sousa & 638051 & $1,134.511$ & 0.025 & 12.196 & 0.770 & 0.999 \\
\hline Juru & 737016 & 950.321 & 0.142 & 11.729 & 0.765 & 0.999 & Sumé & 736026 & $1,121.638$ & 0.158 & 14.136 & 0.789 & 0.997 \\
\hline Mãe D’água & 737015 & $1,234.298$ & 0.263 & 16.956 & 0.814 & 0.991 & Taperoá & 736000 & 887.501 & 0.141 & 11.684 & 0.765 & 0.999 \\
\hline Malta & 637031 & $1,276.634$ & 0.225 & 16.291 & 0.808 & 0.995 & Teixeira & 737002 & $1,141.531$ & 0.137 & 14.285 & 0.790 & 0.997 \\
\hline Mamanguape & 635044 & $1,220.824$ & 0.222 & 15.030 & 0.797 & 0.997 & Triunfo & 638029 & 893.550 & 0.152 & 13.371 & 0.781 & 0.998 \\
\hline Manaíra & 738015 & $1,148.691$ & 0.119 & 13.257 & 0.780 & 0.998 & Uirauna & 638035 & $1,017.264$ & 0.031 & 12.503 & 0.773 & 0.999 \\
\hline Mataraca & 635045 & $1,531.710$ & 0.126 & 13.372 & 0.781 & 0.998 & Umbuzeiro & 735011 & 807.748 & 0.199 & 13.511 & 0.783 & 0.989 \\
\hline
\end{tabular}

${ }^{1}$ The parameters K, a, b and c are defined by Pfafstetter (1982). 
results have been reported in others studies, with the variability in IDF parameters attributed primarily to the different rainfall distribution (Silva et al. 2003b, Santos et al. 2009, Campos et al. 2014).

Silva et al. (2002) also found a wide variation in the estimates of the IDF equation parameters in a study carried out in the Bahia State. For the $\mathrm{K}$ parameter, the estimates ranged from 1121.260 to 8999.000; parameter " $a$ " from 0.174 to 0.245 ; parameter "b" from 19.457 to 56.068 ; and parameter "c" from 0.783 to 1.119. Similarly, Santos et al. (2009) also observed a significant variation for stations assessed in the Mato Grosso do Sul State. These results confirm that the IDF of rainfall is directly linked to its spatial distribution (Silva et al.
2002, Santos. et al. 2010), corroborating the need to determine these parameters for each specific rainfall station.

In most of the equations adjusted by applying the daily rainfall disaggregation methodology, the $\mathrm{r}^{2}$ values were above 0.99 , and of the ninety stations studied, only three exhibited values below 0.99 , the lowest being 0.97 at the Santa Rita station. These results show the good fit of the estimates obtained by the methodology used, in relation to the data observed.

The spatialization of maximum rainfall intensity values with the estimates of the IDF equation parameters shows that the greatest intensities, regardless of duration, occur in the coastal and highlands at the "sertão" of the Paraíba State (Figure 3).
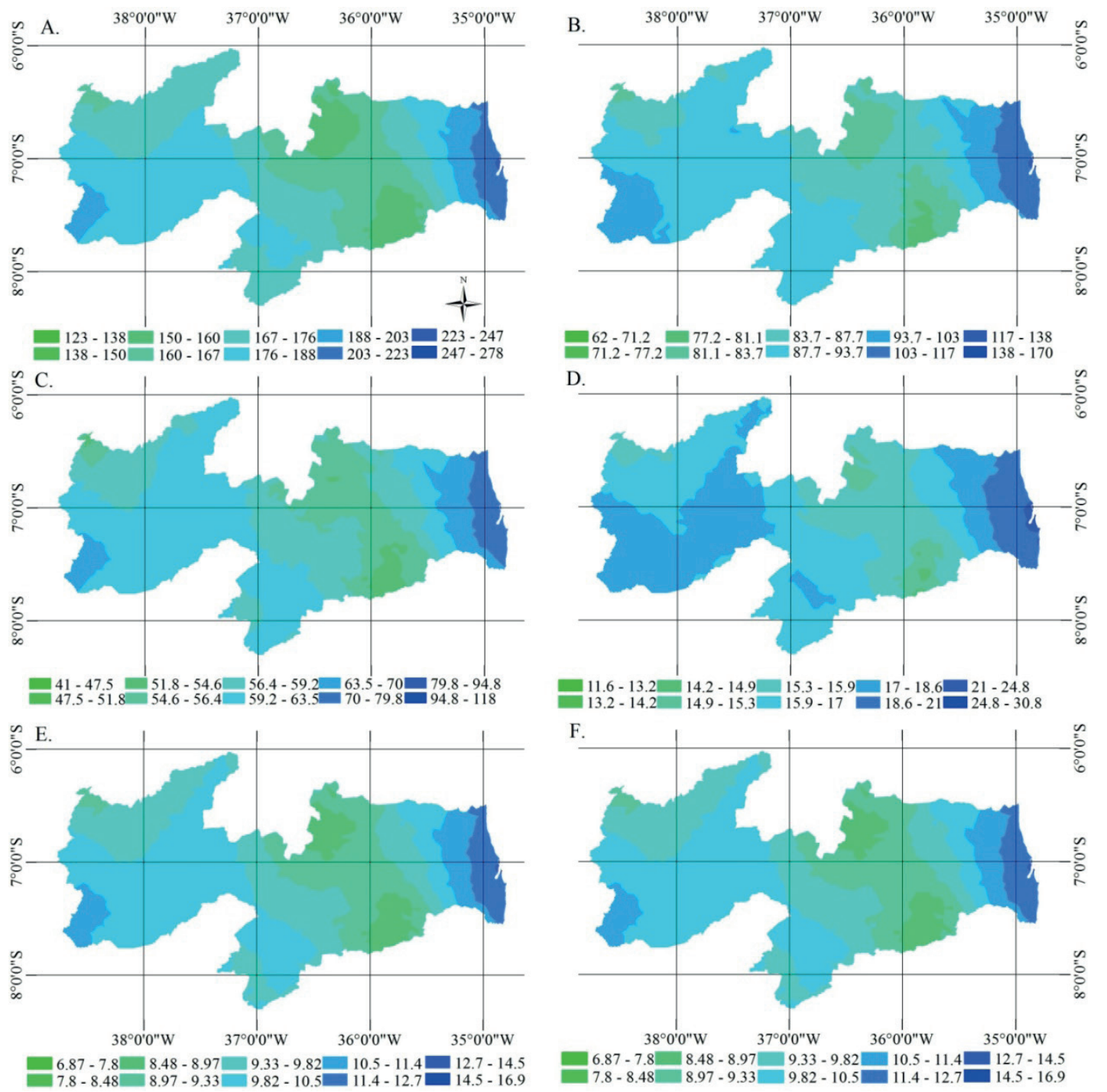

Figure 3. Maximum rainfall intensities $(\mathrm{mm})$ estimated for a return period of 25 years, with the following durations: 5 min (A), $30 \min (\mathrm{B}), 60 \min (\mathrm{C}), 360 \min (\mathrm{D}), 720 \min (\mathrm{E})$ and 1,440 $\min (\mathrm{F})$. 
In general, the spatial distribution of maximum rainfall intensity estimated by the IDF equation corroborates other studies on rainfall pattern in the Paraíba State (Limeira et al. 2012, Silva et al. 2009). These findings demonstrate that the rainfall values estimated for different durations and return periods by IDF equations have a high correlation with the rainfall distribution observed in this region.

\section{CONCLUSIONS}

1. The Log-Normal III distribution model shows a better fit to the data series, for determination of maximum rainfalls for different return periods in the Paraíba State;

2. The intense rainfall equations for most stations showed a good fit, with coefficients of determination above 0.99 , supporting the methodology used in this study;

3. The intensity-duration-frequency (IDF) equation parameters show a wide variation among stations, indicating the need to determine them for each station;

4. The spatialization of the maximum rainfall intensity values with the estimates of IDF equation parameters shows that the highest intensities occur in the regions of coastal and highlands at the "sertão" of the Paraíba State.

\section{REFERENCES}

ARAGÃO, R. et al. Chuvas intensas para o Estado de Sergipe com base em dados desagregados de chuva diária. Revista Brasileira de Engenharia Agrícola e Ambiental, v. 17, n. 3, p. 243-252, 2013.

ARAÚJO, L. E. et al. Análise estatística de chuvas intensas na bacia hidrográfica do Rio Paraíba. Revista Brasileira de Meteorologia, v. 23, n. 2, p. 162-169, 2008.

BACK, A. J. Relações entre precipitações intensas de diferentes durações ocorridas no município de Urussanga, SC. Revista Brasileira de Engenharia Agrícola e Ambiental, v. 13, n. 2, p. 170-175, 2009.

BACK, A. J.; OLIVEIRA, J. L. R.; HENN, A. Durationfrequency relationships of heavy rainfall in Santa Catarina, Brazil. Revista Brasileira de Ciência do Solo, v. 36, n. 3 , p. 1015-1022, 2012.

BRASIL. Agência Nacional de Águas. Hidroweb: sistemas de informações hidrológicas. 2012. Available at: <http:// hidroweb.ana.gov.br>. Access on: Jun. 24, 2012.
CAMPOS, A. R. et al. Equações de intensidade-duraçãofrequência de chuvas para o Estado do Piauí. Ciência Agronômica, v. 45, n. 3, p. 488-498, 2014.

CASTRO, A. L. P. de; SILVA, C. N. P.; SILVEIRA, A. Curvas intensidade-duração-frequência das precipitações extremas para o município de Cuiabá (MT). Ambiência, v. 7, n. 2, p. 305-315, 2011.

CECÍLIO, R. A. et al. Avaliação de interpoladores para os parâmetros das equações de chuvas intensas no Espírito Santo. Ambi-Água, v. 4, n. 3, p. 82-92, 2009.

COMPANHIA DE TECNOLOGIA DE SANEAMENTO AMBIENTAL (Cetesb). Drenagem urbana: manual de projeto. São Paulo: Cetesb, 1979.

COMPANHIA DE TECNOLOGIA DE SANEAMENTO AMBIENTAL (Cetesb). Drenagem urbana: manual de projeto. São Paulo: DAEE/Cetesb, 1986.

DAMÉ, R. C. F.; TEIXEIRA, C. F. A; TERRA, V. S. S. Comparação de diferentes metodologias para estimativa de curvas intensidade-duração-frequência para Pelotas, RS. Engenharia Agrícola, v. 28, n. 2, p. 245-255, 2008.

GARCIA, S. S. et al. Determinação da equação intensidadeduração-frequência para três estações meteorológicas do Estado de Mato Grosso. Revista Brasileira de Engenharia Agrícola e Ambiental, v. 15, n. 6, p. 575-581, 2011.

LIMEIRA, R. C. et al. Tendência das chuvas no Estado da Paraíba. Revista Hispeci \& Lema On Line, v. 1, n. 3, p. 1980-2536, 2012.

LYRA, G. B. I. I. et al. Regiões homogêneas e funções de distribuição de probabilidade da precipitação pluvial no Estado de Táchira, Venezuela. Pesquisa Agropecuária Brasileira, v. 41, n. 2, p. 205-215, 2006.

MARTINS, C. A. S.; ULIANA, E. M.; REIS, E. F. Estimativa da vazão e da precipitação máxima utilizando modelos probabilísticos na bacia hidrográfica do Rio Benevente. Enciclopédia Biosfera, v. 7, n. 13, p. 1130, 2011.

MELLO, E. L. et al. Efeito das mudanças climáticas na disponibilidade hídrica da bacia hidrográfica do Rio Paracatu. Engenharia Agrícola, v. 28, n. 4, p. 635-644, 2008.

MORUZZI, R. B.; OLIVEIRA, S. C. Relação entre intensidade, duração e frequência de chuvas em Rio Claro, SP: métodos e aplicação. Teoria e Prática na Engenharia Civil, v. 1, n. 13, p. 59-68, 2009.

OLIVEIRA, L. F. C. et al. Intensidade-duração-frequência de chuvas intensas para localidades no Estado de Goiás e Distrito Federal. Pesquisa Agropecuária Tropical, v. 35, n. 1, p. 13-18, 2005. 
PFAFSTETTER, O. Chuvas intensas no Brasil. Brasília, DF: Departamento Nacional de Obras e Saneamento, 1957.

SANTOS, E. H. M.; GRIEBELER, N. P.; OLIVEIRA, L. F. C. Relação entre uso do solo e comportamento hidrológico na bacia hidrográfica do Ribeirão João Leite. Revista Brasileira de Engenharia Agrícola e Ambiental, v. 14, n. 8, p. 826-834, 2010.

SANTOS, G. G. et al. Intensidade-duração-frequência de chuvas para o Estado de Mato Grosso do Sul. Revista Brasileira de Engenharia Agrícola e Ambiental, v. 13, suppl., p. 899-905, 2009.

SANTOS, L. C. C. Estimativa de vazões máximas de projeto por métodos determinísticos e probabilísticos. 2010. 173 f. Dissertação (Mestrado em Engenharia Ambiental) - Centro Tecnológico, Universidade Federal do Espírito Santo, Vitória, 2010.

SILVA, B. M. et al. Chuvas intensas em localidades do Estado de Pernambuco. Revista Brasileira de Recursos Hídricos, v. 17, n. 3, p. 135-147, 2012.

SILVA, D. D. et al. Equações de intensidade-duraçãofrequência da precipitação pluvial para o Estado de Tocantins. Engenharia na Agricultura, v. 11, n. 4, p. 7-14, 2003 b.
SILVA, D. D. et al. Chuvas intensas no Estado da Bahia. Revista Brasileira de Engenharia Agrícola e Ambiental, v. 6, n. 2, p. 362-367, 2002.

SILVA, V. P. R. da et al. Análises da precipitação pluvial no Estado da Paraíba com base na teoria da entropia. Revista Brasileira de Engenharia Agrícola e Ambiental, v. 7, n. 2, p. 269-274, 2003a.

SILVA, V. P. R. et al. Estudo da variabilidade anual e intra-anual da precipitação e do número de dias chuvosos no Estado da Paraíba. Revista Ciência da Vida, v. 29, n. 1, p. 50-62, 2009.

SOUSA, H. T. et al. Software sistema computacional para análise hidrológica (SisCAH). Versão 1.0. GPRH. Viçosa: UFV, 2009.

SOUZA, J. A. Estudo das chuvas intensas na zona rural e urbana de João Pessoa. 1972. Dissertação. Escola Politécnica, Universidade Federal da Paraíba, Campina Grande, 1972.

SOUZA, R. O. R. de M. et al. Equações de chuvas intensas para o Estado do Pará. Revista Brasileira de Engenharia Agricola e Ambiental, v. 16, n. 9, p. 999-1005, 2012. 